\title{
Human Evolution and Education in Slovene Schools
}

\author{
Barbara Bajd
}

Published online: 12 September 2012

(C) Springer Science+Business Media, LLC 2012

\begin{abstract}
This article discusses the importance and benefits of providing lower secondary school students with some knowledge of human evolution and its educational context. The author surveyed science teaching in secondary and upper secondary schools in Slovenia and concluded that evolution in general, and human evolution in particular, do not feature prominently in the curriculum and so are not represented by many teaching contact hours. Neither are popular, well-designed, and up-to-date books on the subject-whether by Slovene authors or in translation-readily available to interested students. And yet, paleoanthropology - the study of human evolution in its wider context - is a rapidly developing, high-profile branch of science with major popular appeal. Recent discoveries-many of them spectacular - have provided a much more detailed picture of human evolutionary history, significantly modifying earlier ideas about our ancestry. The subject not only attracts much public interest but also has major educational benefits: human evolution exemplifies many general evolutionary principles, illustrates the synergy of focused multidisciplinary approaches in the life sciences, and reinforces teaching of environmental conservation, human relations, and social responsibility. Because of the subject's importance, the author provides some suggestions on how the teaching of human evolution might be incorporated into the school curriculum and considers some of the educational resources available to support its teaching.
\end{abstract}

Keywords Evolution $\cdot$ Paleoanthropology $\cdot$ School curriculum

\footnotetext{
B. Bajd $(\bowtie)$

Faculty of Education, University of Ljubljana,

Ljubljana, Slovenia

e-mail: barbara.bajd@guest.arnes.si
}

\section{Introduction}

Human evolution is a rapidly changing subject of great public appeal, as any survey of international press, television, and radio will reveal. Popular accounts tend to focus on the fossil evidence for human ancestry and particularly on discoveries of new specimens, but the investigation of human origins has a much broader scope than just the fossil record. Paleoanthropology - the study of human evolution in its broadest context-includes not only the information provided by fossilized bones and teeth, but also the archaeological, geological, climatic, faunal, and chronological evidence relating to our forebears. Paleoanthropology is thus multidisciplinary, with its aim to reveal not just the past pattern of human evolution but also the behavior, social organization, ecology, and adaptation of early humans and their prehuman ancestors.

Because of paleoanthropology's wide subject range, I will limit my considerations in this article to where, and to what extent, the evolution of man is included in programs in Slovene schools. In brief, we can summarize the position by noting that we do not pay much attention to this subject in schools, nor even in the Slovenian media.

And yet each of us has a natural interest in our origins, and it is important to tap into that curiosity and to use it as a means of imparting information and ideas about human evolution that can be used to exemplify broader concepts in the life sciences and to encourage an appreciation of biological diversity. So primary and secondary schools could profitably pay more attention to this subject. Young children display a spontaneous natural interest in nature, in their environment, and also in organisms that lived in the past. Typically, they are especially interested in dinosaurs, which they learn about from books, videos, and movies. From this, it is a natural extension to have an interest in how humans evolved, how early man behaved, and what our 
ancestors looked like. Moreover, there can be important additional benefits in incorporating some treatment of human evolution in the primary curriculum.

Its study at even an elementary level responds to children's natural interest and curiosity about their origins. It serves to illustrate many important principles and aspects of evolution generally and has important additional benefits. One important theme in human success has been the crucial importance of social developments (group size and structure, personal relationships, cooperation, language, the development of technology) influencing biological evolution. Another is the increasing control by humans of their environment, emphasizing the interconnections between ourselves and our surroundings. And a final, important benefit is that knowledge of our evolution underlines both the importance of the individual (each of us is unique) and, since we all share a common origin and important attributes, emphasizes the commonality of all human beings. This is important to counter "us versus them" attitudes, racism, excessive nationalism, chauvinism, and xenophobia, all of which contributed much to human misery throughout the twentieth century.

\section{Paleoanthropology: History and Context}

Paleoanthropology is a relatively young science, developing rapidly since the first human fossils were recognized in the middle of the nineteenth century. Its origin can be conveniently dated from the discovery of a partial skeleton in the Feldhofer Cave in the Neandertal (Valley) along the River Dussel in 1856. In 1859, the pre-Biblical antiquity of man was confirmed by discoveries in northern France, the same year as Darwin's Origin of Species was published. These revolutionized interpretations of biological diversity, and the notion of evolution through natural selection rapidly became the dominant paradigm in biology. Although the implications were obvious, Darwin himself was cautious about explicitly applying his ideas to man, but some of his followers - notably Thomas Huxley in England and Ernst Haeckel in Germany-argued powerfully that evolution had molded humans as well as other species. During the same period (roughly the third quarter of the nineteenth century), increasing archaeological evidence confirmed the reality of "Ice Age" man as a contemporary of now extinct animals such as the mammoth and woolly rhinoceros.

By the last quarter of the nineteenth century, both our animal (as opposed to divine) origins and our antiquity as a species were widely accepted - so much so that some workers quite explicitly set out to discover the "missing links" that would document our evolution. By the turn of the twentieth century, the evidence was sufficiently comprehensive and persuasive for the notion of human evolution to be the established scientific orthodoxy and for creationism to be in retreat even within religious circles. ${ }^{1}$ However, the actual fossil record of human evolution was still comparatively sparse, with most specimens having been discovered by chance through quarrying, railway construction and building, or geological fieldwork. With the single exception of Pithecanthropus from Java, finds were confined to Europe (mainly Germany, Belgium, France, and Croatia), but after World War I, new discoveries in Palestine and China extended the geographical and temporal ranges of human evolution.

During the same period, the first finds from South Africa pointed toward a much earlier, African origin for hominids (the primate family to which humans and their immediate ancestors belong) and so for the roots of mankind. Over the last 40 years, extensive discoveries - many of them spectacular-have augmented that record, extending it to East and Central Africa and demonstrating that continent to have been the setting for crucial hominid adaptations such as truncal erectness and bipedalism, fine manipulation and tool making, and rotary chewing and thus effective food processing. Crucial though these African discoveries have been for revealing evidence of the earliest phases of human evolution, finds have not been confined to that continent. Over the same period, major discoveries in Asia and Europe have similarly expanded our knowledge of early occupation of those regions and have led to a dramatic lengthening of the timescale since hominids expanded beyond the tropics.

A striking feature of this most recent phase of paleoanthropological investigation, especially when compared with earlier work, is its complex, multidisciplinary nature. Discoveries are no longer made by heroic isolated figures but by large teams of anthropologists, paleontologists earth scientists, archaeologists, physicists, and chemists. The aim is not simply to recover the hominid fossils themselves, but to build up a detailed picture of their habitats and to reconstruct as far as possible their ecology and behavior. In other words, earlier hominids are viewed not simply as potential human ancestors, but as specific organisms in their own right, interacting with, and responding to, the changes in their environments.

This shift of emphasis together with the much expanded fossil record has led to a radically different view of hominid evolution. Instead of a single evolutionary tree with one main stem leading inexorably to modern humans, the most generally accepted view is of a radiating bush with multiple branches, each representing a particular species of hominid. Workers currently recognize at least eight species of Australopithecus (erect, part bipedal, part arboreal, smallbrained, and large-faced early hominids) and six or more

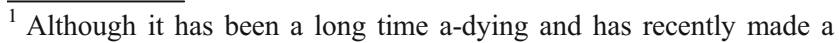
comeback, especially in the United States.
} 
species of early Homo (bigger-brained, fully terrestrial bipedal hominids more closely resembling modern humans). As the number of species multiplies, so does the frequency of hominid extinction since, clearly, not all these species can be directly ancestral to ourselves. This leads in turn to a different view of evolutionary processes and patterns: the evolution of modern humans was not an inevitable, longterm consequence of the hominid evolutionary process but rather the outcome of chance events and fluctuating environmental conditions impacting on small, scattered populations of early hominids. A slightly different set of habitats and hominid groups would have resulted in radically different evolutionary outcomes.

Although most recent attention has focused on Africa, there have been dramatic developments elsewhere. Recent finds in Spain extend human occupation of Western Europe back from about a half-million years ago to more than 1.3 million years ago. Until only a few years ago, it was widely believed that hominids in the form of early Homo erectus first migrated beyond Africa about 1.4 million years ago. We now know, thanks to recent discoveries at Dmanisi, near Tbilisi, Georgia, that $H$. erectus had reached the "Gates of Europe" by at least 1.8 million years ago (Gabunia 2000). As the evidence expands, equally dramatic reevaluations and changes of perspective can be confidently expected in the foreseeable future.

\section{What Is the Situation in Slovenia?}

From the 1930s, and especially immediately following World War II, paleoanthropology was well developed in Slovenia, largely due to the work of Prof. Božo Škerlj, whose research and scientific publications made him an internationally known figure. In addition to numerous papers, he also published many anthropological books, and through his influence, paleoanthropology was clearly represented in programs and associated textbooks for lower and upper secondary schools.

As early as 1934, Škerlj (1934) published his book Man, and from immediately after the war and through the 1950s, he produced several accounts of paleoanthropology and human evolution. In 1946, Škerlj (1946) published Origin and Evolution of Man (Škerlj 1946); in 1947, General Anthropology (with a second edition in 1959); and in 1950, Human Evolution (Škerlj 1950). There followed Unpleasant Relationship (Škerlj 1955) and, after his death in 1963, the book Thinking Biped (Škerlj 1963). All these were aimed at students of anthropology and combined scientific accuracy with an accessible, popular style so that they could be read by a wide spectrum of readers, both young and adult.

It is relevant to note that Darwin's (1951) Descent of Man, which was published in England in 1871, was translated into the Slovene language 80 years later in 1951, and his Origin of
Species, published in England in 1859, was translated into Slovene in 1954.

In 1962, the influential and popular survey of human evolution, Mankind in the Making by William Howells (1962), was translated into Slovene, but we had to wait another 37 years for a comparably authoritative overview of the subject in our language- The Fossil Trail by Ian Tattersall (1999).

This marked contrast in access to extended accounts of human evolution in Slovenian over the last five decades is difficult to explain. Publishers will doubtless retort that we are a small nation, and the market for books in the Slovene language reflects this fact. Furthermore, they will argue that the readership for such specialized subjects is tiny and therefore uncommercial. But this ignores both the interest shown in Skerlj's time and the worldwide popularity of paleoanthropology today. Has Slovenian curiosity in our origins effectively disappeared over the last 50 years, in contrast to public attitudes in just about every other western country? I think not. Rather, the likely explanation is that Slovenian readers are largely unaware of recent developments in this fascinating area. And the single most important reason for this lack of awareness is that the subject does not now feature in the school curriculum.

Božo Škerlj was not the only figure concerned to bring his subject to the attention of a wider audience. Back in 1947, Professor Polenc (1947) published Evolution of the Living World and, in 1981, Man, on the Evolution trail, both written for younger readers. The latter book is richly illustrated and presents human evolution to children in an attractive and interesting way, so that they get an idea of what our ancestors looked like. But unfortunately, because of the pace of discovery in human evolution, such accounts, while attractive and accessible to children, are no longer full or accurate. This is important, because the much-expanded fossil evidence has not provided "more of the same" but rather led to a radically different view of human evolution (see above).

A brief account of recent Slovenian history and the situation in our schools is relevant here. Slovenia is a young and independent country. It gained international recognition in 1992, having previously been a part of the Federal Republic of Yugoslavia. With the disintegration of the old socialist system, socioeconomic changes occurred, and Europeanization and globalization of the new society took place. There were also changes in the education system, in both educational objectives and in the curriculum. The most immediately apparent was in the prolongation of primary education, i.e., in the transition from eight-year to nine-year primary school. The new curriculum was gradually implemented, and by 2001/ 2004, all primary schools were teaching to the new curriculum. The first nine years of schooling are compulsory, and so their content, subjects, and objectives determine children's knowledge and understanding before their period of further 
study or of employment. So it is important that pupils in the first nine years of schooling acquire knowledge not only of mathematics, languages, geography, chemistry, and physics but also of biology, including the evolution of living organisms and also some treatment of human evolution. In the last year of the old eight-year curriculum, the whole pupil group studied evolutionary theory within the framework of biology. They acquired knowledge of the origin of the Earth, through the first plants and animals and the evolution of organisms, and were introduced to human evolution. Students in higher grades also acquired further knowledge of evolution and human evolution, but these were only the minority of students who continued study in secondary schools. If it is considered important for all pupils to learn something of evolution, then it must be included within the compulsory school curriculum.

\section{Initial Curricula in Slovenian Education}

While paleoanthropology and evolutionary studies generally are rapidly expanding and are influential areas of biology worldwide, regrettably, in the Slovene lower secondary school curriculum, biological evolution and especially human evolution are represented by only a few hours of teaching. In class eight (of the nine-year schooling), biology as a whole includes some specified topics, with a total of 52 teaching hours. The topic "classification and evolution" was reduced to some chapters which pupils studied for only a few hours at school. The aim of this part of the curriculum is to make pupils aware of man's evolutionary development. For example, they should be able to explain why we classify man within Mammals and Primates and be able to describe major stages in his evolutionary development. All this seems appropriate and even laudable, but the reality is rather different. For within the time constraints imposed by the curriculum, it is effectively impossible for pupils to acquire an adequate grasp of the topic.

Additional support for any move to increase the teaching of evolution in our schools was provided by the results of the TIMMS study, based on data collected in May and June 1995. More than 40 countries from across the world participated, and children aged nine and 13 in each country were asked the same questions under the most consistent possible circumstances, so that the results could be compared directly. In Slovenia, 371 class seven and 344 class eight children answered questions on evolution. Of these, $41 \%$ of class seven children and $52 \%$ of class eight pupils answered correctly that in the evolutionary timescale, humans appeared relatively late. However, the international average for the correct response was $60 \%$, so that Slovenian children were well below average. Swedish pupils scored the highest correct responses (89.4\%), with children from Denmark, New Zealand, Australia, France, USA, Austria, Norway, England, Thailand, and Iceland all scoring over $80 \%$. By contrast, among Slovenian class seven children, more than half thought that the latest animals to evolve were insects. These results should give us cause for concern, for they indicate that our children know little of biodiversity and evolution in general, not just human evolution.

In upper secondary schools, the teaching program and the number of hours allotted to subjects differ according to the type of school. Those schools having 175 hours of biology or, in some cases, even more (210 hours) in their programs, as in general secondary schools (gymnasia) have five hours on the teaching of human evolution. Schools with fewer than 175 hours of biology teaching have no human evolution at all in their curriculum.

In addition to the - at best - very limited time available to treat human evolution, there is a structural problem. When taught, it is usually placed towards the end of the school year, so that it is often squeezed out by the overrunning of earlier topics and/or the buildup to exam preparation. In many cases, therefore, the topic is covered cursorily if at all, and pupils do not take it as seriously as those parts of the biology syllabus covered earlier in the year.

In the syllabus for A level Biology with Ecology, introduced in 2002 for external assessment, there were specified objectives in terms of content which the students are expected to have covered by the time of examination. Within the section on evolution, students are expected to achieve the following objectives in relation to human evolution:

- To classify humans within a taxonomic framework

- To summarize and explain the adaptations primates show to their arboreal habitat

- To correlate with climatic and vegetation changes the transition of primate species from arboreality to savannah living and the development of erect walking in hominids, and to set these shifts within a chronological framework

- To summarize the anatomical changes associated with erect posture and bipedal locomotion in hominids

- To summarize the adaptive advantages of erect posture (especially the freeing of the forelimbs from locomotion and the subsequent development of manipulative dexterity) and the use of tools and fire

- To recognize the importance of brain evolution for human evolution

- To appreciate the role of positive feedback between biotic and psychosocial evolution, with special attention to speaking and language, in the evolution of human intelligence

- To compare Neanderthal and modern humans and indicate the periods when these forms were living

As we can see, the syllabus for 2002 includes treatment of several fundamental structural and adaptive changes important for human evolutionary success. Even so, it does not 
expect from the student much knowledge of the actual pattern of human evolution or the kinds of earlier hominids, their features and adaptations. The only premodern form specifically mentioned is Neanderthal man - the latest and, in the view of many workers, the most parochial of premodern humans. Students are not expected to know about earlier hominid species and their specific characteristics, when the fundamental structural adaptations that they are expected to know about were first evolving.

All this can, of course, be explained in terms of the constraints of available time and the need for a balanced curriculum. And it can be argued that it is more important for students to acquire a sound grasp of the adaptive fundamentals underpinning human success, rather than the details of how, when, and where these evolved, and in what sequence. And were the requirement for a detailed knowledge of the pattern of human evolution to be incorporated within the syllabus, there would be a continuing need for refresher courses for teachers to keep them abreast of new discoveries.

However, it is necessary to have some idea of the pattern of human evolution to fully appreciate the significance of those basic adaptations such as bipedalism and manual dexterity that are represented within the syllabus. Moreover, to include only Neanderthal man without reference to any earlier hominids makes very little sense, for then Neanderthals are left floating, without any chronological or evolutionary referents. So we should at least explore the possibility of providing additional information for students through supplementary support materials which fill out the essential background.

Within higher education, the situation is rather better, with human evolution taught in two faculties of the University of Ljubljana. All biology students and those training to be biology teachers have lectures of the subject, covering the main features of fossil hominids, major sites, together with major adaptive and evolutionary patterns. Similarly, archaeology students also take a course on human evolution. For some years, students in the Department of Sociology within the Faculty of Arts studied social anthropology and within this subject also had lectures on human evolution and primatology. However, other students-for instance those studying history - received no teaching of human evolution. Unfortunately in the school year 2009/2010, the new Bologna program, designed to harmonize European higher education qualifications, was accepted in all Slovene universities, which reduced the range of former university programs, and so students of sociology and cultural anthropology had no further lectures on human evolution.

\section{Revised Curricula in Slovenian Education}

In 2011, revised curricula for primary and lower and upper secondary schools were introduced. In year eight, biology was allocated 64 hours of study with the following objectives: biology and society, research and experiments, chemistry of living systems, inheritance, biotechnology, evolution, classification of organisms, biotic variety, biomes and biosphere, influence of man on nature and the environment. In the evolution chapter, there is only one objective concerning human evolution. That is: "Pupils should know about and can explain the origin of primates and humans, as well as the relationships of humans and other primates." In my opinion, the pupils will not gain sufficient knowledge of human evolution, and the curriculum has too many objectives to be satisfactorily covered in the available teaching hours. So pupils will learn facts by heart and will not understand them, because there will be not enough time to really teach to the objectives and impart understanding of evolution. I can say from experience that within the period of compulsory schooling, our pupils will not acquire a satisfactory knowledge of evolution and particularly human evolution.

In upper secondary school (gymnasium), pupils have three years of biology with 210 hours in total. Within this framework, 25 hours are devoted to learning about evolution. Among the 18 targets pupils have to study within the 25 hours, there is only one objective relating to human evolution: Pupils should know the major stages in human evolution (Australopithecus afarensis, H. erectus, Homo sapiens, and expansion out of Africa). I am afraid that within the compressed timetable for evolutionary topics, pupils will simply not have sufficient time to gain an adequate overview of human evolution and will not properly comprehend current interpretations of human ancestry, especially now so many early hominin species are recognized.

Of course, pupils can acquire their knowledge from a variety of sources besides school: through their reading of books, magazines, and comics, through watching TV, increasingly through using computers to access the internet, and through visits to galleries, museums, and exhibitions. Unfortunately, in the Natural History Museum in Ljubljana, there is no presentation at all about human evolution.

The only significant exhibition of human evolution in Slovenia is one based upon a private collection, the property of Mr. Milan Kovač which is now situated in Postojna. Another private exhibition was set up in 1996 at the Firšt inn in Logarska dolina to display the finds from Potočka zijalka. Unfortunately, there is no guide, supporting material, or other publication about the exhibition, from which interested visitors can obtain further information about the finds and their significance. Potočka zijalka was excavated from 1928 by Professor Srečko Brodar. Although it did not yield any human fossils, the site is important in attesting to Upper Pleistocene hunters in Slovenia. Brodar excavated more than 300 stone tools as well as more than 130 bone artifacts, clear evidence of human activity at the site. He also recovered bones of the now-extinct cave bear. Professor 
Polenc (1981) writes in his book Man, On the Evolution Trail:

Brodar was digging throughout the school holidays with insufficient financial support, in very difficult conditions and with modest resources. Every day, in all weathers he had to walk, with some volunteers and with two or three paid workers, on the mountain path from the village St. Duh $(1,250 \mathrm{~m}$ to the cave. The only support he had was from the museum in Celje, but this was extremely modest. The political climate then was not sympathetic to archaeology or any activity that did not bring immediate profit. Moreover, many politicians of the day, influenced by their own upbringing and the Church's continuing influence, resisted the notion of man's natural origins and antiquity. In spite all these difficulties Brodar persisted in his excavations, displaying the determination of an enthusiastic and dedicated scientist with the courage of his convictions.

I must also mention the extremely important finding of a possible bone flute, discovered in 1995 in Mousterian levels at the site of Divje babe near Idrija (Turk 1997). However, not all workers are absolutely convinced that the object is a flute or that its dating is correct. If further studies show that it is a flute and really is from the Neanderthal period, the find will be the oldest musical instrument in the world and evidence of the early development of a particular aspect of human culture.

\section{What Can We Do to Ensure That Slovenian Students Acquire More Knowledge and Understanding of Human Evolution?}

Given overall constraints on the school timetable, it is realistic to plan on the assumption that there will be no increased teaching time for biology in the secondary curriculum. This is despite the fact that the life sciences are at least as important as other school subjects and that issues of ecology, biological diversity, and conservation are increasingly topics of public concern. A necessary precondition for the protection of our natural environment is an appreciation of the scale and pattern of biodiversity and recognition of its sensitive interconnectivity. This is where knowledge of evolution - the central unifying theory of biology - is of crucial importance. And to understand man's place in the living world and the significance of his interactions with other species in turn requires some knowledge of human evolution.

If these arguments are accepted, then ways of introducing more teaching of human evolution will nonetheless need to be found. One possible way is to explore the connections between aspects of human evolution and other subjects, interweaving them into the teaching of (for example) history, sociology, art, and geography. This would have the added benefits of promoting pupils' awareness of the value of diversity and the richness of experience that it provides. It would counter tendencies toward stereotypical thinking, encourage pupils to recognize the positive importance of variability, and promote tolerant attitudes to other individuals, nationalities, cultures, and creeds. In other words, teaching human evolution in this way will not only provide pupils with a sound knowledge of many important concepts in the biological sciences but also help promote their social responsibility and citizenship. We live in an increasingly interconnected world in which individual, regional, and national prosperity will depend not only upon technical and economic expertise, but also upon the ability to extend those beyond national frontiers and to interact constructively with people with very different backgrounds from our own.

Such an interweaving of topics also has pedagogic benefits in encouraging pupils to think flexibly, to counter the tendency to compartmentalize knowledge into separate "boxes," and to avoid the overloading of the curriculum with facts to be memorized by rote. Within such a flexible framework, it may eventually be possible to provide older pupils with an optional (or facultative) treatment of human evolution as a supplement to the core curriculum.

At university level, some treatment of paleoanthropology could usefully be incorporated within the course framework for students of geography and history, for example. And we should encourage the publication of accounts of the subject, whether textbooks or shorter popular articles explaining specific aspects and current developments, either as original accounts or in translation. Without access to some such seed corn accounts, popular interest is unlikely to develop as it has elsewhere, and no Slovenian author has written wide-ranging, authoritative, and yet accessible accounts since Škerlj.

\section{Possible Ways Forward}

A major raising of public awareness in the subject would have followed the Congress of Paleoanthropology in Slovenia planned for 2001. Unfortunately, plans for this had to be abandoned following the tragic death in a climbing accident of Professor Iztok Saksida, its main organizer. However, a preliminary and exploratory meeting had already been convened by Prof. Saksida, and the review papers given at that meeting by several workers who had planned involvement were published in a memorial volume as Pliocene and Pleistocene Hominids (Bajd and Kavur 1999). Twelve years later, another meeting on human evolution was organized with invited participants including distinguished paleoanthropologists such as Dr. Ian Tattersall (American Museum of National History, New York), Prof. Dr. Winifred Henke (Johannes Gutenberg-University Mainz), William E.H. Harcourt-Smith (American Museum of National History, New York), Prof. Joel 
Rak (Department of Anthropology, Sackler Faculty of Medicine, Tel Aviv University), Dr. Theodoros Pitsios (Medical school, University of Athens), Prof. Gunther Brauer (University of Hamburg), and Dr. Barbara Bajd (University of Ljubljana, Faculty of Education). For this occasion, a book with the title Where Did We Come From? Current Views on Human Evolution was published in English (Bajd 2010). Regrettably there were insufficient funds to translate it into the Slovene language and make it available to a larger number of Slovene readers.

A timely catalyst for raising public awareness would be the mounting of a major new exhibition on the subject in the Natural History Museum in Ljubljana. It is almost 40 years (Polenc 1975) since the last such display, and a silver jubilee exhibition-perhaps coinciding with the 25th anniversary of an independent Slovenia - would emphasize to people the fundamental changes over that period, the richness of present evidence, the exciting pace of development in the subject, and our interconnectedness in an increasingly small world. And this theme of interconnectedness would sit very well with Slovenia's status as a small but proud and independent nation concerned to reach out to other countries within Europe and beyond. Anton Polenc (1981) in his book for children Man quotes Charles Darwin's prophetic sentence: "the light also started to shine on man's evolution and his history." Let us hope that light will start to shine on Slovene paleoanthropology again in the sense of teaching and learning.

\section{Postscript}

These thoughts are intended not as a criticism of those other workers who have struggled with limited resources over the years to continue the teaching of paleoanthropology in Slovenia, but rather to stimulate discussion of the pedagogic value of human evolution and to argue for its enhanced role within the curriculum of Slovene schools.

\section{References}

Bajd B. Where did we come from? Current views on human evolution. University of Ljubljana, Faculty of Education; 2010

Bajd B, Kavur B. Pliocenski in pleistocenski hominidi, knjižna zbirka Scripta, ŠOU, Študentska založba Ljubljana; 1999

Darwin C. Izvor človeka, Slovenski knjižni zavod v Ljubljani, Zbirka Poljudnoznanstvena knjižnica št. 30; 1951

Gabunia L, et al. Earliest Pleistocene homind cranial remains from Dmanisi, Republic of Georgia: taxonomy, geological setting, and age. Science. 2000;288:1019-25.

Howells W. Nastajanje človeštva. Ljubljana: Državna založba Slovenije; 1962.

Polenc A. Razvoj živega sveta. Ljubljana: DZS; 1947.

Polenc A. Izvor človeka, vodnik po razstavi, Prirodoslovni muzej Slovenije; 1975

Polenc A. Človek, po sledeh razvoja. Ljubljana: Mladinska knjiga; 1981.

Škerlj B. Človek. Ljubljana: Založba tiskarne Merkur; 1934.

Škerlj B. Izvor in razvoj človeka. Ljubljana: Slovenski književni zavod; 1946.

Škerlj B. Razvoj človeka (antropogeneza). Ljubljana: DZS; 1950.

Škerlj B. Nevšečno sorodstvo. Ljubljana: Mladinska knjiga; 1955.

Škerlj B. Misleči dvonožec. Ljubljana: Mladinska knjiga; 1963.

Tattersall I. Po sledi fosilov. Kaj si mislimo, da vemo o človeški evoluciji, Zbirka Sophia 4/99, Znanstveno publicistično središče, Ljubljana; 1999.

Turk I. (ured.). Musterienska koščena piščal, Založba ZRC, Ljubljana; 1997. 